\title{
Contribution of starter lactococci and adjunct lactobacilli to proteolysis, volatile profiles and sensory characteristics of washed-curd cheese
}

\author{
Erica HYNES ${ }^{\mathrm{a}}$, Cyrille BACH ${ }^{\mathrm{b}}$, Gilles LAMBERET ${ }^{\mathrm{b}}$, Jean-Claude OGIER ${ }^{\mathrm{b}}$, \\ Olivier SON ${ }^{b}$, Agnès DELACROIX-BUCHET ${ }^{\mathrm{b} *}$ \\ a Facultad Ingenieria Quimica, Santiago del Estero 2829, (3000) Santa Fe, Argentina \\ b Unité de Recherches Laitières et Génétique Appliquée (URLGA), INRA, Domaine de Vilvert, \\ 78352, Jouy-en-Josas Cedex, France
}

(Received 16 July 2001; accepted 26 April 2002)

\begin{abstract}
Washed-curd cheeses manufactured with either Lactococcus lactis subsp. lactis IL416 or Lactococcus lactis subsp. cremoris AM2 were used to test the role of six Lactobacillus strains from the CNRZ collection as adjunct cultures. Proteolysis and volatile profile determinations were performed on all cheeses after 28 days of ripening; a trained panel assessed sensory characteristics. We observed that overall, the lactococcal starter strains had a major influence on cheese taste and texture. Control cheeses manufactured with the strain IL416 were mild. Lactobacilli adjunct addition to cheeses manufactured with the strain IL416 had a strong effect on their flavour attributes. In contrast, control cheeses manufactured with the strain AM2 had greater flavour intensities and were saltier and more acidic. These cheeses were more affected in their texture profile and overall flavour intensity, and to a lesser extent in their flavour profile by lactobacilli addition. In summary, while the major cheese characteristics are determined by the starter strain used, addition of lactobacilli adjuncts L. plantarum 1572, L. plantarum 1310 and L. casei 1227 can affect flavour and texture of washed-curd cheese products.
\end{abstract}

Lactobacilli adjunct culture / starter / proteolysis / volatile compound / sensory property

Résumé - Contribution du levain et d'une culture secondaire de lactobacilles à la protéolyse, au profil des composés volatils et aux caractéristiques sensorielles de fromages à pâte pressée. Des fromages à pâte pressée ont été fabriqués avec soit Lactococcus lactis subsp. lactis IL416, soit Lactococcus lactis subsp. cremoris AM2 pour tester le rôle de six souches de lactobacilles de la collection CNRZ en tant que culture secondaire. La protéolyse et le profil des composés volatils ont été déterminés sur tous les fromages après 28 jours d'affinage et un jury entraîné a établi leur profil sensoriel. Nous observons avant tout une influence majeure de la souche de levain lactocoque sur le goût et la texture des fromages. Les fromages témoins fabriqués avec la souche IL416 sont neutres et l'ajout d'une culture secondaire de lactobacilles a un fort impact sur les attributs de flaveur de ces fromages. Au contraire, les fromages témoins fabriqués avec la souche AM2 possèdent une plus forte intensité de flaveur, ils sont plus salés et plus acides. La texture et l'intensité globale de flaveur et, dans une moindre mesure, le profil de flaveur de ces fromages sont aussi davantage affectés par

* Correspondence and reprints

Tel.: 331346520 92; fax: 331346520 65; e-mail: delacroi@ jouy.inra.fr 
l'apport d'une culture secondaire de lactobacilles. En résumé, si les caractéristiques principales des fromages sont déterminées par la souche de levain, l'ajout d'une culture secondaire des souches de lactobacilles L. plantarum 1572, L. plantarum 1310 ou L. casei 1227 peut modifier la flaveur et la texture de fromages à pâte pressée.

Culture secondaire de lactobacilles / levain / protéolyse / composé volatil / propriété sensorielle

\section{INTRODUCTION}

Non-starter lactic acid bacteria (NSLAB) are adventitious lactic acid bacteria that contaminate cheese. In contrast to starter lactic acid bacteria, which are inoculated into cheese milk at high cell concentrations and decline during the ripening period, NSLAB initial counts are very low $\left(10^{2}\right.$ to $10^{4} \mathrm{CFU} \cdot \mathrm{mL}^{-1}$ in good quality commercial raw milk and 10 to $10^{4} \mathrm{CFU} \cdot \mathrm{g}^{-1}$ in one-dold Cheddar cheese manufactured with pasteurised milk) but they increase (up to $10^{7}-10^{8} \mathrm{CFU} \cdot \mathrm{g}^{-1}$ ) during the first weeks of ripening $[8,27]$. NSLAB comprise mainly lactobacilli in cheeses manufactured with pasteurised milk, but may also include pediococci and entero-cocci $[5,23,26]$.

NSLAB probably contaminate cheese milk after pasteurisation [21]. However, very small percentages of NSLAB may also survive pasteurisation [36] and be the source of secondary flora in "aseptic" cheeses. Alternatively, lactobacilli present in cheeses manufactured with pasteurised milk may be part of the resident flora in the dairy production plant [25], and in the raw milk itself [36].

The influence of lactobacilli in cheese ripening has been studied by adding lactobacilli cultures as adjunct flora to experimental cheeses $[15,16,19,28,34]$ or by comparing cheeses manufactured either with raw or pasteurised milk [23, 29, 30]. In most cases, cheeses with higher counts of NSLAB have a higher free amino acid (FAA) content and enhanced flavour, although acceptability is not always improved [3, 18, 19, 35]. Water-soluble or $70 \%$ ethanol-soluble extracts of cheeses manufactured with and without added lactobacilli were shown to have quantitative differences [19]. Furthermore, experimental Cheddar cheese containing a complex adjunct culture of mesophilic lactobacilli developed a stronger flavour than the control [24], and experimental cheeses also had a higher score for flavour intensity than controls [34, 35]. It has been suggested that lactobacilli adjunct cultures may indirectly improve cheese flavour by limiting growth of adventitious and potentially prejudicial NSLAB [21]. However, other studies suggest that lactobacilli are not needed to obtain a good quality Gouda cheese [14] and may even be detrimental to the flavour quality of Cheddar cheeses [37]. Taking into account these diverse studies, Peterson and Marshall [27] suggested that NSLAB influence is probably dependent on the strain and the final bacterial count. Temperature and the starter strain used $[10,15]$ also play a role in the growth of NSLAB and their influence on cheese ripening.

In this work, we examined the contribution of starter and lactobacilli adjunct culture to proteolysis, production of volatile compounds and sensory characteristics of washed-curd cheeses (Saint-Paulin). For that purpose, six Lactobacillus strains were tested individually as adjunct culture with two different starter strains.

\section{MATERIALS AND METHODS}

\subsection{Strains and cheese manufacture}

All strains were from the CNRZ collection. Lactobacillus strains that had been isolated from cheese [31] were tested in cheese experiments as adjunct culture. Two strains of $L b$. plantarum, identified by 
Table I. Trial planning for washed-curd cheeses. AM2: L. lactis subsp. cremoris strain AM2; IL416: L. lactis subsp. lactis strain IL416. Trials with the same identification letter (example: A and A') were made with the same milk. Each trial corresponds to a cheese-making day. C: control cheese (without lactobacilli); E1 and E2 experimental cheeses (with lactobacilli). Experimental cheese 1 from trial C was not manufactured because adjunct culture $L$ b. casei 1244 did not attempt the appropriated optical density on time.

\begin{tabular}{|c|c|c|c|c|}
\hline Week number & Trial & Cheese & Starter & Adjunct culture \\
\hline \multirow{6}{*}{1} & \multirow{3}{*}{ A } & $\mathrm{C}$ & \multirow{3}{*}{ IL416 } & - \\
\hline & & E1 & & Lb. casei 1227 \\
\hline & & E2 & & Lb. plantarum 1572 \\
\hline & \multirow{3}{*}{$A^{\prime}$} & $\mathrm{C}$ & \multirow{3}{*}{ AM2 } & - \\
\hline & & E1 & & Lb. casei 1227 \\
\hline & & E2 & & Lb. plantarum 1572 \\
\hline \multirow{6}{*}{2} & \multirow{3}{*}{ B } & $\mathrm{C}$ & \multirow{3}{*}{ IL416 } & - \\
\hline & & E1 & & Lb. casei 1219 \\
\hline & & E2 & & Lb. casei 1308 \\
\hline & \multirow{3}{*}{$\mathrm{B}^{\prime}$} & $\mathrm{C}$ & \multirow{3}{*}{ AM2 } & - \\
\hline & & E1 & & Lb. casei 1219 \\
\hline & & E2 & & Lb. casei 1308 \\
\hline \multirow{6}{*}{3} & \multirow{3}{*}{$\mathrm{C}$} & $\mathrm{C}$ & \multirow{3}{*}{ IL416 } & - \\
\hline & & E1 & & Lb. casei 1244 \\
\hline & & E2 & & Lb. plantarum 1310 \\
\hline & \multirow{3}{*}{$\mathrm{C}^{\prime}$} & $\mathrm{C}$ & \multirow{3}{*}{ AM2 } & - \\
\hline & & E1 & & Lb. casei 1244 \\
\hline & & E2 & & Lb. plantarum 1310 \\
\hline
\end{tabular}

numbers 1310 and 1572 , and four $L b$. case $i$ $(1219,1227,1244$ and 1308) were selected from results in model miniature cheeses [11]. Washed-curd cheeses (220 g) with and without added lactobacilli were manufactured in $6 \mathrm{~L}$ vats either with CNRZ starter strain L. lactis subsp. lactis IL416 (chosen for its high resistance to phage infection [4]) or with L. lactis subsp. cremoris AM2 (chosen for its autolytic ability due to the presence of a prophage [17]). Two experimental cheeses and one control cheese were obtained every cheesemaking day, according to planning (Tab. I).

A disinfectant product (Divosan 2000, Diversey-Lever, Fontenay-sous-Bois, France) was pulverised in the cheese-making room $24 \mathrm{~h}$ before production to prevent phage attack and contamination with adventitious lactobacilli. The vats and cheese-making tools were soaked in a hypochlorite solu- tion (concentration $1 \mathrm{~g} \cdot \mathrm{L}^{-1}$ ) for $10 \mathrm{~min}$ and not rinsed before use.

Whole pasteurised commercial milk was inoculated with starter culture (either IL416 or AM2). Milk of the same batch was used two consecutive days for cheese production with the two starter strains and using the same Lactobacillus test strains. Lactobacilli were added to the experimental cheese milk. Starter and adjunct cultures were prepared as previously described [11]. Three batches of milk were used to complete the whole experimental design in three weeks.

Renneting was carried out at $32{ }^{\circ} \mathrm{C}$ using $0.03 \%(\mathrm{v} / \mathrm{v})$ rennet $(520 \mathrm{mg}$ active chymosin $\mathrm{L}^{-1}$, Granday, SKW, Beaune, France). Lactose was partially removed from the curd by substituting $40 \%(\mathrm{v} / \mathrm{v})$ of the whey with sterile water at $32{ }^{\circ} \mathrm{C}$ while stirring. The curd was moulded and 
pressed overnight at $25^{\circ} \mathrm{C}$. The cheeses were brined for $3 \mathrm{~h}$ at $10^{\circ} \mathrm{C}$, surface dried and waxed. They were ripened for $28 \mathrm{~d}$ at $12{ }^{\circ} \mathrm{C}$. Gross composition of one-d-old cheeses $(\mathrm{pH}$, fat and dry matter, $\mathrm{NaCl}$ content) was determined as described [11].

\subsection{Analyses}

\subsubsection{Bacteriological analysis and phage detection}

The population of starter lactococci present in the cheese products after 1,14 and $28 \mathrm{~d}$ of ripening was determined by plating sample dilutions on M17 agar and after $48 \mathrm{~h}$ of incubation at $30^{\circ} \mathrm{C}$ [32]. To determine the population of NSLAB, samples were also plated on Lactobacilli Selection Agar (LBS, Baltimore Biological Laboratories, Rockville, USA) and incubated for $72 \mathrm{~h}$ under anaerobic conditions [20]. The absence of lytic phages during cheese-making was verified as described previously [13].

\subsubsection{Assessment of proteolysis}

Cheese samples were treated to obtain crude citrate extracts, insoluble and soluble fractions at $\mathrm{pH} 4.4$ and the soluble fraction in phosphotungstic acid (PTA), according to Gripon et al. [9]. Nitrogen content of the fractions was determined in duplicate by the macro-Kjeldahl method according to the IDF Standard 20B [12].

Ethanol $70 \%$ soluble extracts of cheeses, prepared as described [18], and insoluble fractions at $\mathrm{pH} \mathrm{4.4,} \mathrm{were} \mathrm{ana-}$ lysed by reverse phase liquid chromatography (RP-HPLC). A $25 \mathrm{mg}$ casein sample was dissolved in $1.5 \mathrm{~mL}$ of a Bis-Tris buffer $\left(0.02 \mathrm{~mol} \cdot \mathrm{L}^{-1}, \mathrm{pH} 6.5\right)$ also containing urea $\left(4 \mathrm{~mol} \cdot \mathrm{L}^{-1}\right)$ and $\beta$-mercaptoethanol $(0.3 \%)$ and analysed as described [39] HPLC equipment and chromatographic conditions were as described by Hynes et al. [11].
The relation between the peak area for $\alpha s 1$ casein and the peptide $\alpha$ s $1-\mathrm{I}$, resulting from chymosin activity, $\% \frac{\alpha \mathrm{s} 1-\mathrm{I}}{\alpha \mathrm{s} 1-\mathrm{I}+\alpha \mathrm{s} 1}$, was calculated as an index of primary proteolysis.

Free amino acids (FAA) were quantified as described [17].

\subsubsection{Preparation and analysis of volatile compounds}

Volatile compounds of control and experimental cheeses were compared qualitatively by a rapid method based on static headspace analysis by gas chromatography (GC). A sample of $5 \mathrm{~g}$ of cheese and $5 \mathrm{~g}$ of $\mathrm{Na}_{2} \mathrm{SO}_{4}$ were mixed in a glass vial $(22 \mathrm{~mL})$ provided with a glass rod through a Teflon septum. After mixing, the vial was cooled in an ice-water bath and the cap was substituted by a Mininert valve (Interchim, Monluçon, France). The vial was then warmed up in a water bath to $60{ }^{\circ} \mathrm{C}$ for $15 \mathrm{~min}$. A sample of $400 \mu \mathrm{L}$ of the gas phase was taken with a gas syringe (SGE, Villebon, France) and injected splitless into the chromatograph. Gas chromatography was performed in a HRGC 5160 Mega Series (Carlo Erba instruments, Thermo Quest, Les Ulis, France) equipped with a flame ionisation detector and with an FFAP column ( $\mathrm{J} \& \mathrm{~W}$, Folson, USA), length $12 \mathrm{~m}$, internal diameter $0.52 \mathrm{~mm}$, film thickness $1 \mu \mathrm{m}$. The initial oven temperature was $35^{\circ} \mathrm{C}$. After $2 \mathrm{~min}$, the temperature was increased at $30^{\circ} \mathrm{C} \cdot \mathrm{min}^{-1}$ to $125^{\circ} \mathrm{C}$, and at $5^{\circ} \mathrm{C} \cdot \mathrm{min}^{-1}$ to $150{ }^{\circ} \mathrm{C}$, where it was held for $7 \mathrm{~min}$. The flow rate of the carrier gas $\left(\mathrm{H}_{2}\right)$ was $5 \mathrm{~mL} \cdot \mathrm{min}^{-1}$. The injector temperature was $150{ }^{\circ} \mathrm{C}$, and the detector temperature was $200{ }^{\circ} \mathrm{C}$.

Data were collected with a Kontron PC Integration Pack (Kontron Instruments, Montigny, France). Peak identification was carried out by standard addition of pure compounds and confirmed by GCMS (chromatograph 8060 and MD 800, Fisons Instruments, Thermo Quest, Les Ulis, 
France). Chromatography was carried out using a Supelco Wax column, $30 \mathrm{~m}$, i.d. $0.32 \mathrm{~mm}$, phase thickness $1 \mu \mathrm{m}$. The vector gas $\left(\mathrm{H}_{2}\right)$ velocity was $50 \mathrm{~cm} \cdot \mathrm{s}^{-1}$. The injection temperature was $260{ }^{\circ} \mathrm{C}$ with a split after $30 \mathrm{~s}$. The $35^{\circ} \mathrm{C}$ oven temperature was maintained for $3 \mathrm{~min}$, then raised at $7{ }^{\circ} \mathrm{C} \cdot \mathrm{min}^{-1}$ to $150{ }^{\circ} \mathrm{C}$, this temperature maintained for $2 \mathrm{~min}$. After electronic impact ionisation $(70 \mathrm{eV}$, detector $400 \mathrm{~V}$, mass range $14-150 \mathrm{~m} / \mathrm{z}$ ), mass spectra were compared with those of the NIST mass spectra library.

\subsubsection{Sensory analysis}

The sensory properties of 28-d-old washed-curd cheeses were assessed by a 12-member trained panel [38] in a room adapted for sensory analyses [1]. During each session, two experimental cheeses (prepared with lactobacilli adjunct culture) and one control cheese (without lactobacilli) corresponding to one cheese-making day were simultaneously compared by each panel member in a sensory profiling test. Cheeses were removed from storage, waxed off, stored at room temperature for $1 \mathrm{~h}$ and cut into portions ( $25 \mathrm{~g})$ before sensory evaluation. Cheese portions were covered with glasses for odour assessment and labelled with randomised 3-number codes. The order in which the cheese portions were presented to the panel was balanced to avoid order and carry-over effects. Mineral water and bread were provided to the panellists to rinse their mouth between samples. The panel was asked to note odour intensity on a 5-point scale and to describe the olfactory, visual (aspect), and tactile (hand touching) sensations perceived during examination of the cheese portions. Samples were then rated according to 3 texture attributes (firmness, elasticity and perceptibility of the micro-structure: from unctuous to granular), 7 flavour attributes (salty, sweet, acid, bitter, pungent, fruity, rancid), overall flavour intensity, and overall quality. A 5-point rating scale was used with $0=$ undetected,
$1=$ very low, $2=$ low, $3=$ medium and $4=$ strong.

Data were analysed using the Tastel software system version 2000 (ABT informatique, Paris, France). Principal Component Analysis (PCA) was carried out on the cheese characteristics [2].

\section{RESULTS}

\subsection{Gross composition}

The composition of the one-d-old washed-curd cheeses is shown in Table II. Differences in dry matter and salt-in-moisture were detected between control cheeses manufactured with the same batch of milk two consecutive days but with different starters, or between control cheeses manufactured with three different batches of milk but with the AM2 starter. They were probably due to the low coagulating quality of pasteurised milk used in the experiments, which caused differences in the syneresis of curd during cheese-making. Commercial pasteurised milk was selected because it was originally used in the screening of the strains in miniature model and was constant in gross composition. Average $\mathrm{pH}$ values were lower than usual in Saint-Paulin-like cheeses (5.205.30 ), probably because higher whey retention in our model resulted in more extensive amounts of available lactose.

\subsection{Microbiological analysis}

The number of lactococci and lactobacilli in cheeses with and without adjunct culture during ripening for the two tested starters are shown in Table III. The bacterial counts of L. lactis IL416 remained constant during ripening (above $10^{9} \mathrm{UFC} \cdot \mathrm{g}^{-1}$ of cheese), thus indicating the good stability of the starter population. Lactobacilli did not dominate the microflora of the cheeses, as their population remained constant throughout the ripening period, while control cheeses remained free of adventitious lactobacilli. 
Table II. Dry matter \% (DM), salt-in-moisture \% (S/M) and $\mathrm{pH}$ values for washed-curd cheeses with and without lactobacilli adjunct. C: control (without lactobacilli); E1 and E2 experimental cheeses (with lactobacilli); numbers in brackets indicate the Lactobacillus strain.

\begin{tabular}{lccccccccc}
\hline Starter IL416 & \multicolumn{3}{c}{ Trial A } & \multicolumn{3}{c}{ Trial B } & \multicolumn{3}{c}{ Trial C } \\
\hline Cheese & C & E1 & E2 & C & E1 & E2 & C & E1 & E2 \\
& & $(1227)$ & $(1572)$ & & $(1219)$ & $(1308)$ & & $(1244)$ & $(1310)$ \\
DM $(\%)$ & 51.37 & 50.89 & 51.47 & 50.53 & 51.29 & 51.62 & 50.13 & 49.35 & 50.85 \\
S/M (\%) & 3.66 & 4.52 & 2.51 & 3.7 & 2.27 & 2.73 & 2.65 & 2.96 & 2.75 \\
pH & 4.91 & 4.91 & 4.92 & 4.88 & 4.89 & 4.90 & 4.83 & 4.84 & 4.81 \\
\hline Starter AM2 & & Trial A' & & & Trial B' & & & Trial C' & \\
\hline Cheese & $\mathrm{C}$ & E1 & E2 & C & E1 & E2 & C & E1 & E2 \\
DM $(\%)$ & & $(1227)$ & $(1572)$ & & $(1219)$ & $(1308)$ & & $(1244)$ & $(1310)$ \\
S/M $(\%)$ & 50.04 & 50.55 & 49.12 & 50.96 & 48.49 & 50.68 & 47.72 & - & 46.40 \\
$\mathrm{pH}$ & 3.20 & 2.75 & 4.20 & 2.87 & 3.51 & 3.04 & 2.63 & - & 2.46 \\
& 4.80 & 4.77 & 4.78 & 4.81 & 4.82 & 4.77 & 4.72 & - & 4.70 \\
\hline
\end{tabular}

Table III. Bacteriological counts (CFU. $\mathrm{g}^{-1}$ ) at 1,14 and $28 \mathrm{~d}$ of ripening of washed-curd cheeses made with either IL416 (L. lactis subsp. lactis strain IL416) or starter AM2 (L. lactis subsp. cremoris strain AM2), with and without lactobacilli adjunct. C: control (without lactobacilli); E1 and E2 experimental cheeses (with lactobacilli); numbers in brackets indicate Lactobacillus strain.

\begin{tabular}{|c|c|c|c|c|c|c|c|c|c|c|}
\hline \multicolumn{2}{|c|}{ Starter IL416 } & \multicolumn{3}{|c|}{ Trial A } & \multicolumn{3}{|c|}{ Trial B } & \multicolumn{3}{|c|}{ Trial C } \\
\hline & $\begin{array}{l}\text { Ripening } \\
\text { day }\end{array}$ & C & $\begin{array}{c}\text { E1 } \\
(1227)\end{array}$ & $\begin{array}{c}\text { E2 } \\
(1572)\end{array}$ & C & $\begin{array}{c}\text { E1 } \\
(1219)\end{array}$ & $\begin{array}{c}\text { E2 } \\
(1308)\end{array}$ & C & $\begin{array}{c}\text { E1 } \\
(1244)\end{array}$ & $\begin{array}{c}\text { E2 } \\
(1310)\end{array}$ \\
\hline \multirow[t]{3}{*}{ Lactococci } & 1 & $4.410^{9}$ & $5.610^{9}$ & $4.710^{9}$ & $4.410^{9}$ & $3.310^{9}$ & $5.110^{9}$ & $3.710^{9}$ & $2.210^{9}$ & $3.710^{9}$ \\
\hline & 14 & $3.510^{9}$ & $3.510^{9}$ & $410^{9}$ & $410^{9}$ & $3.610^{9}$ & $4.610^{9}$ & $2.410^{9}$ & $1.710^{9}$ & $2.810^{9}$ \\
\hline & 28 & $2.910^{9}$ & $1.710^{9}$ & $3.110^{9}$ & $1.910^{9}$ & $2.710^{9}$ & $1.410^{9}$ & $3.910^{9}$ & $2.210^{9}$ & $1.910^{9}$ \\
\hline \multirow[t]{3}{*}{ Lactobacilli } & 1 & $7.110^{3}$ & $5.1310^{8}$ & $810^{7}$ & $<10^{2}$ & $710^{7}$ & $5.510^{8}$ & $<10^{2}$ & $4.410^{7}$ & $3.210^{8}$ \\
\hline & 14 & $<10^{2}$ & $310^{8}$ & $7.310^{7}$ & $<10^{2}$ & $4.810^{7}$ & $410^{8}$ & $<10^{2}$ & $7.410^{7}$ & $2.510^{8}$ \\
\hline & 28 & $<10^{2}$ & $5.910^{8}$ & $8.610^{7}$ & $<10^{2}$ & $9.510^{7}$ & $3.510^{8}$ & $<10^{2}$ & $7.410^{7}$ & $2.310^{8}$ \\
\hline \multicolumn{2}{|c|}{ Starter AM2 } & \multicolumn{3}{|c|}{ Trial A' } & \multicolumn{3}{|c|}{ Trial B' } & \multicolumn{3}{|c|}{ Trial C' } \\
\hline & $\begin{array}{l}\text { Ripening } \\
\text { day }\end{array}$ & $\mathrm{C}$ & $\begin{array}{c}\text { E1 } \\
(1227)\end{array}$ & $\begin{array}{c}\text { E2 } \\
(1572)\end{array}$ & $\mathrm{C}$ & $\begin{array}{c}\text { E1 } \\
(1219)\end{array}$ & $\begin{array}{c}\text { E2 } \\
(1308)\end{array}$ & $\mathrm{C}$ & $\begin{array}{c}\text { E1 } \\
(1244)\end{array}$ & $\begin{array}{c}\text { E2 } \\
(1310)\end{array}$ \\
\hline \multirow[t]{3}{*}{ Lactococci } & 1 & $1.110^{9}$ & $1.110^{9}$ & $1.110^{9}$ & $1.810^{9}$ & $1.510^{9}$ & $1.510^{9}$ & $1.110^{9}$ & - & $2.610^{9}$ \\
\hline & 14 & $<10^{6}$ & $<210^{5}$ & $<210^{5}$ & $310^{6}$ & $6.610^{7}$ & $<210^{5}$ & $310^{6}$ & - & $<210^{5}$ \\
\hline & 28 & $<210^{5}$ & $<210^{5}$ & $<210^{5}$ & $<210^{5}$ & $<210^{5}$ & $<210^{5}$ & $<210^{5}$ & - & $<210^{5}$ \\
\hline \multirow[t]{3}{*}{ Lactobacilli } & 1 & $<10^{2}$ & $7.410^{8}$ & $810^{7}$ & $<10^{2}$ & $6.410^{7}$ & $3.510^{8}$ & $310^{3}$ & - & $4.510^{8}$ \\
\hline & 14 & $<10^{2}$ & $7.410^{8}$ & $7.310^{7}$ & $<10^{2}$ & $5.610^{7}$ & $4.310^{8}$ & $<210^{5}$ & - & $2.610^{8}$ \\
\hline & 28 & $<10^{2}$ & $1.610^{8}$ & $8.610^{7}$ & $3.210^{4}$ & $1.210^{8}$ & $3.410^{8}$ & $710^{5}$ & - & $3.610^{8}$ \\
\hline
\end{tabular}


Table IV. Nitrogen content in soluble fraction at $\mathrm{pH} 4.4$, and in phosphotungstic acid $2.5 \%$, expressed as a percentage of total nitrogen (\% $\mathrm{pH} 4.4 \mathrm{SN} / \mathrm{TN}$ and \% PTA-SN/TN, respectively), for the 28-d-old washed-curd (control and experimental cheeses) manufactured either with starter IL416 or starter AM2.

\begin{tabular}{ccc}
\hline & \multicolumn{2}{c}{ Starter strain } \\
\hline Mean values (n=9) & IL416 & AM2 \\
$\% \mathrm{pH}$ 4.4-SN/TN & $16.1 \pm 0.5$ & $17.4 \pm 1.1$ \\
$\%$ PTA-SN/TN & $0.8 \pm 0.1 *$ & $2.3 \pm 0.7$ \\
\hline *This value is near to the detection limit of the \\
method and therefore may not be exact.
\end{tabular}

In contrast to IL416, the L. lactis AM2 population markedly decreased during cheese ripening, possibly due to autolysis by activated prophage. The evolution of the lactobacilli population in experimental cheeses prepared with the AM2 starter was essentially the same as that observed in cheeses manufactured with IL416 starter. Control cheeses prepared with AM2 alone, however, showed some contamination with adventitious lactobacilli (up to $7.10^{5} \mathrm{UFC} \cdot \mathrm{g}^{-1}$ ) for two batches out of three; this did not occur in control cheeses manufactured with the strain IL416.

\subsection{Proteolysis}

The average contents of soluble nitrogen at $\mathrm{pH} 4.4(\mathrm{SN})$, and phosphotungstic acid-soluble nitrogen (PTA-N) of cheese inoculated with either the starter IL416 or AM2 at $28 \mathrm{~d}$ of ripening are shown in Table IV. Washed-curd cheeses made with and without lactobacilli had practically identical SN levels, both for IL416 and AM2 starters (individual values not shown). PTA-N levels were very low for cheeses manufactured with the strain IL416, near the detection limit of the method, and thereby the variability coefficient was not acceptable for this series. $L b$. plantarum 1310 was the only adjunct that resulted in an increase of PTA-N values compared with the control cheeses $(0.7 \%)$.

Chromatograms of the $70 \%$ ethanolsoluble extracts showed similar results to those already observed in model miniature cheeses [11] i.e. quantitative (total surface area) and qualitative differences between peptide profiles of cheeses prepared with starter IL416 or AM2 and essentially quantitative (peak areas) differences between control and experimental cheeses manufactured with the same starter (data not shown). This suggests that the starter strains play a more important role than the lactobacilli adjunct in the production of 70\% ethanol-soluble peptides.

The chromatographic profiles of the insoluble fraction at $\mathrm{pH} 4.4$ were essentially the same for all cheeses (data not shown). The relation $\% \frac{\alpha \mathrm{s} 1-\mathrm{I}}{\alpha \mathrm{s} 1-\mathrm{I}+\alpha_{\mathrm{s} 1}}$ was $36.2 \pm 0.2 \%$ for control cheeses, and $38.6 \pm 2.4 \%$ for experimental cheeses. These values are not significantly different $(P<0.05)$.

Total amounts of FAA for 28-d-old washed-curd cheeses are shown in Figure 1. There was a clear difference between cheeses manufactured with starter IL416 or AM2. For cheeses manufactured with the strain AM2, FAA amounts were greater in both control and experimental cheeses. Note that the Lb. plantarum 1310 adjunct increased the level of FAA by around $30 \%$ for experimental cheeses manufactured with either IL416 or AM2 starters, compared with control cheeses. Lb. casei 1227 showed a similar tendency in cheeses manufactured with the strain IL416, but the increase was much more pronounced (a two-fold increase) in cheeses manufactured with the starter AM2. Lb. plantarum 1572 and Lb. casei 1308 increased FAA content only in washed-curd cheeses manufactured with the strain AM2.

The individual FAA profiles are shown in Figure 2. Profiles reflected the starter strain used rather than the presence of lactobacilli, with higher Glu and Leu contents for the strain AM2. The adjunct generally increased the level of all FAA, but it did not change the general characteristics of the profile except for cheeses made with $L$. plantarum 1310 adjunct, in 

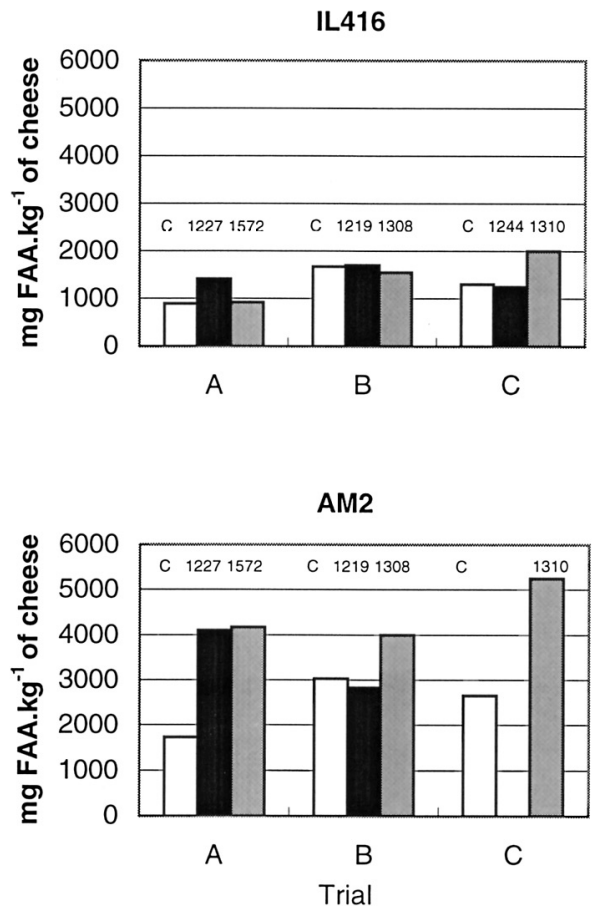

Figure 1. Total amount of free amino acids of 28-d-old washed-curd cheeses with (E, experimental) or without (C, control) added lactobacilli. Lactobacillus strains are identified in the figure.

which higher histidine content was measured regardless of the starter strain used.

\subsection{Volatile compounds}

Gas chromatographic profiles of cheese headspace were very simple. Table V reports the main volatile compounds and their amounts (expressed as integration units) in the headspace of washed-curd cheeses. A first component in the chromatographic profiles, with a retention time shorter than acetaldehyde, was not identified and appeared with most of the adjunct cultures (4/6 with the starter IL416 and 3/4 with the starter AM2). All the other compounds are the usual volatile components of cheese [22].
Adjunct cultures of $L$. casei 1227 and $L$. plantarum 1310 and 1572 showed the greatest difference between control and experimental cheeses made with starter IL416. Headspace profiles for washedcurd cheeses made with starter AM2 were essentially the same, except for $L$. plantarum 1310 (Tab. V).

\subsection{Sensory analysis}

The choice of strains of Lactococcus or adjunct Lactobacillus significantly influenced both the texture and the overall odour intensity and flavour attributes of the product. To summarise the results and simplify their interpretation, principal component analysis (PCA) is shown in a sensory 3-dimensional-space map. $70.1 \%$ of the variance was included in three Principal Components (PC) (Fig. 3a). The first PC, which explained $38.7 \%$ of the variance, was associated with the elastic texture in opposition to the firm, granular texture and salty, acid overall flavours. The second PC (18.0\% of the variance) was mainly determined by the bitter flavour, as opposed to the fruity, rancid and sweet flavours. The third PC (13.4\% of the variance) was dominated by the sweet and pungent flavours as opposed to the odour intensity. Analyses of the three PC from PCA of all the washedcurd cheese sensory data (Fig. 3b) revealed clear separation of cheeses manufactured with starters IL416 and AM2 both on the basis of flavour and texture attributes. A large dispersal of the three control cheeses manufactured with the starter AM2 according to the first PC was observed, probably due to their higher variability in gross composition. Cheeses manufactured with the starter AM2 had the highest flavour intensity; they were more salty and acid, while the sensory characteristics of washed-curd cheeses manufactured with starter IL416 were mild and similar. This is presumably due to the greater activity of endogenous peptidases in cheeses manufactured with the strain AM2. The role of the lactobacilli adjunct, determined by sensory analysis, 
Table V. Volatile compound amounts in washed-curd cheese, expressed as peak areas $\left(\mathrm{mV} \cdot \mathrm{min}^{-1}\right)$ of the headspace analysis by GC. Values of control cheese (manufactured with starter IL416 or AM2 without lactobacilli adjunct) are the average of the three control cheeses. Experimental cheese values are reported individually for each lactobacilli adjunct culture. Lactobacillus strains marked with an asterisk indicate that there were other peaks (unidentified) in the volatile profile of these experimental cheeses. Experimental cheese with AM2 starter and Lb. casei 1227 and 1244 as adjunct culture were not analysed.

\begin{tabular}{lllllllll}
\hline Starter & Compound & $\begin{array}{l}\text { Control } \\
\text { cheese }\end{array}$ & $\mathbf{1 3 1 0} *$ & $\mathbf{1 5 7 2}$ & $\mathbf{1 2 1 9}$ & $\mathbf{1 3 0 8}$ & $\mathbf{1 2 2 7} *$ & $\mathbf{1 2 4 4}$ \\
\cline { 2 - 8 } & unidenfified & 0.07 & 1.13 & 0.09 & 0 & 0.14 & 0.15 & 0 \\
& acetaldehyde & 0 & 0 & 0 & 0 & 0 & 0 & 0 \\
& acetone & 0 & 0.21 & 0.08 & 0 & 0 & 0.12 & 0 \\
& ethyl acetate & 0 & 0.20 & 0 & 0 & 0 & 0.03 & 0 \\
& ethanol & 1.31 & 2.30 & 1.27 & 1.54 & 1.21 & 1.32 & 1.25 \\
& diacetyl & 0.06 & 0.12 & 0 & 0.08 & 0.12 & 0.15 & 0.07 \\
AM2 & acetoin & 0.44 & 0.66 & 0.48 & 0.75 & 0.41 & 0.28 & 0.24 \\
& acetic acid & 0.10 & 0.05 & 0.12 & 0 & 0.02 & 0 & 0 \\
\hline & Compound & $\mathbf{C o n t r o l}$ & $\mathbf{1 3 1 0} *$ & $\mathbf{1 5 7 2}$ & $\mathbf{1 2 1 9}$ & $\mathbf{1 3 0 8}$ & & \\
& cheese & & & & & & \\
& acetaldentified & 0 & 0 & 0.32 & 0.91 & 0.19 & & \\
& acetone & 0.14 & 0.14 & 0 & 0.05 & 0.161 & & \\
& ethyl acetate & 0 & 0 & 0 & 0 & 0 & & \\
& ethanol & 2.49 & 3.23 & 2.25 & 1.61 & 0 & & \\
& diacetyl & 0.052 & 0.08 & 0 & 0 & 0.06 & & \\
& acetoin & 0.24 & 0.64 & 0.13 & 0.04 & 2.56 & & \\
& acetic acid & 0 & 0.08 & 0 & 0 & 0.40 & & \\
\end{tabular}

was also different in cheeses made with the two different starters. A limited number of attributes were found to describe the key characteristics of cheese texture and flavour that were modified by the addition of lactobacilli. Cheeses manufactured with the starter IL416 were most affected in their flavour attributes as a result of lactobacilli adjunct addition. In contrast, cheeses manufactured with the starter AM2 were more affected in their texture profile and overall flavour intensity, and to a lesser extent in their flavour profile, by lactobacilli addition.

\section{DISCUSSION}

In this study, we provide information about the evolution of populations of starter and adjunct cultures and their biochemical activities, during the ripening of washed-curd cheeses.

While starter IL416 viable cell counts remained constant during ripening, the AM2 population decreased to $\sim 10^{5} \mathrm{CFU} \cdot \mathrm{g}^{-1}$ in control cheeses, as expected, because of autolysis due to activated prophage. The survival of the IL416 starter was very similar to the survival we found for the same strain in a model miniature cheese [11]. The starter AM2's viability decreased to lower levels in washed-curd cheeses than in our model, probably because washed-curd cheeses composition determined a more stressful environment for this strain, that led to the prophage activation [17]. Lactobacilli bacterial counts remained at their initial levels. The lactobacilli population at 

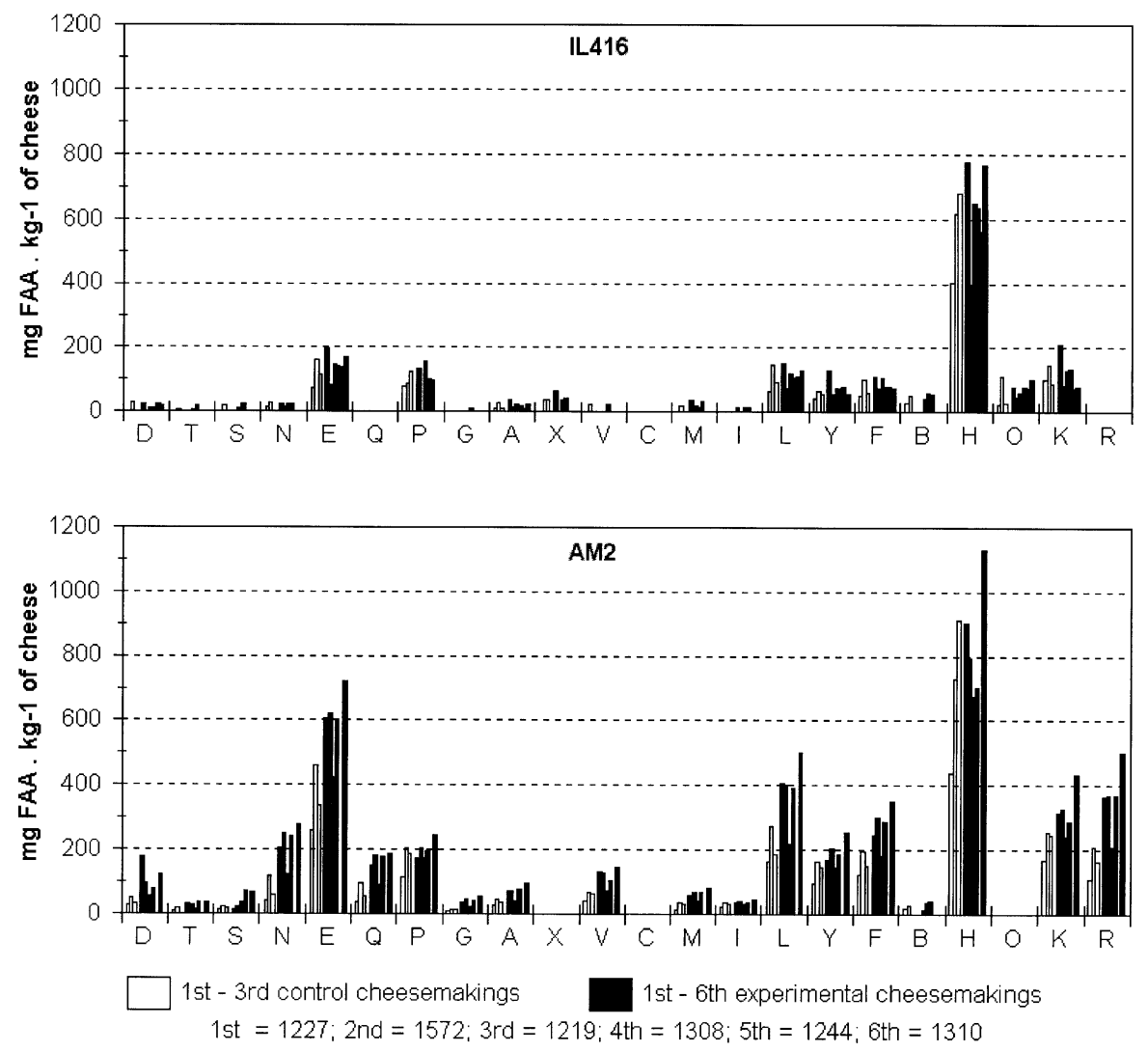

Figure 2. Profiles of free amino acids for 28-d-old washed-curd cheeses manufactured with starter strains IL416 or AM2. Control cheeses are identified with the starter code and the experimental cheeses with the starter and the adjunct codes. AM2+1244 not manufactured. Amino acids are identified by the one letter code ( $\mathrm{X}$ is citrulline, $\mathrm{B}$ is $\gamma$-aminobutyric acid, $\mathrm{O}$ is ornithine).

one day of ripening probably reflects a balance between the loss of cells in whey and the concentration effect due to cheesemaking, but some growth during manufacture and pressing is also possible. Compared with IL416, the presumed lysis of the AM2 strain did not improve growth of Lactobacillus strains. Thomas [33] demonstrated that lactobacilli are able to grow on lactococcal cell homogenate, so it is generally supposed that lytic starters improve lactobacilli development in cheese $[6,21]$. We did not observe such an improvement for lactobacilli adjunct in our experiment.
Note that Lane et al. [15] reported similar results for four types of starter, among them the AM2 strain. It is interesting to note, however, that cheeses manufactured with the starter AM2 were more easily contaminated with adventitious NSLAB than those manufactured with the starter IL416. In our model miniature cheese, we found that AM2 survival was improved in the presence of lactobacilli adjunct cultures [11]. Such a tendency was not verified in washed-curd cheeses, probably because the higher dry-matter and S/M were more stressful conditions for the AM2 

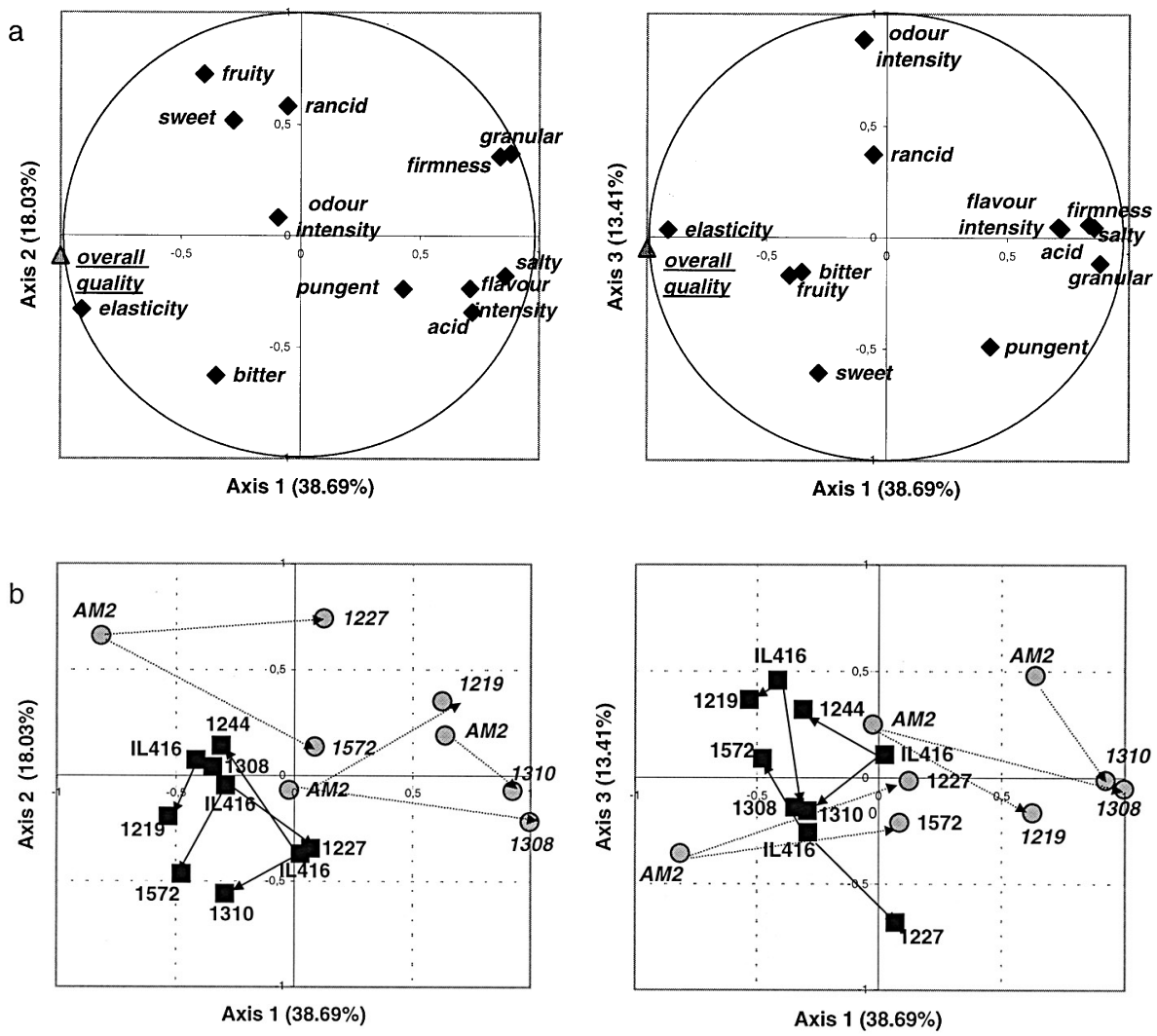

Figure 3. Principal Component Analysis of the sensory data of washed-curd cheeses made either with IL416 (ם) or AM2 (O) L. lactis strains with and without lactobacilli adjuncts. (a) Score of the sensory attributes in the sensory space defined by the first three principal components (70.1\% of the variance). The overall quality is considered as supplementary variate. (b) Location of the products in the sensory space. Control cheeses are identified with the starter code and the experimental cheeses with the adjunct codes.

starter. Micro-filtered milk has been adopted to further examine the effects of adjunct lactobacilli on AM2 in our laboratory.

Primary proteolysis was very similar for control and experimental cheeses, manufactured with either AM2 or IL416, showing that starter and adjunct culture did not significantly influence the hydrolysis of intact caseins in situ. The similarity of SN at $\mathrm{pH} 4.4$ and the $\% \frac{\alpha \mathrm{s} 1-\mathrm{I}}{\alpha \mathrm{s} 1-\mathrm{I}+\alpha_{\mathrm{s} 1}}$ values for experimental and control cheeses also confirmed the repeatability of washed- curd cheeses, as it depends on chymosin activity and, therefore, on water activity, $\mathrm{pH}$ and composition [7].

Several authors have reported that lactobacilli adjunct increased FAA in Cheddar cheese [3, 18, 19, 35]. In washed-curd cheese, increased amounts of FAA in cheeses with lactobacilli depended on the starter strain. Thus, L. casei 1227 and 1219, and L. plantarum 1572 and 1310 strongly incremented the FAA total amount when they were added to cheeses made 
with AM2, but only L. casei 1227 and $L$. plantarum 1310 increased FAA when they were added to cheeses manufactured with the strain IL416. Moreover, the increment in FAA content was as great as double for cheeses manufactured with the strain AM2 with 1227, 1572, 1308 and 1310 Lactobacillus strain adjuncts, but only around 30 to $50 \%$ for L. casei 1227 and L. plantarum 1310 in cheeses manufactured with the starter IL416. These results could be explained by a higher protease and peptidase activity provided by AM2, which would supply more substrates (peptides) for lactobacilli enzymes.

The impact of lactobacilli adjunct on flavour was greater in mild flavoured cheeses manufactured with starter IL416 than in cheeses made with AM2. This observation is in agreement with the greater impact of lactobacilli on volatile compound profiles of cheeses manufactured with the strain IL416. Cheeses manufactured with AM2 starter had a more intense flavour, and therefore the impact of lactobacilli adjunct was not detected in the individual descriptor of flavour, but rather in texture and flavour intensity.

To summarise, the lactobacilli population dominates during more than half the ripening period in cheeses manufactured with starter the AM2, as a consequence of a decrease in the starter population. Nevertheless, their impact on cheese composition and sensory characteristics was not always higher than in cheeses made with the strain IL416, where lactobacilli remained the minor bacterial population. These results underline the importance of synergy between starter and Lactobacillus strains on cheese characteristics.

\section{ACKNOWLEDGEMENTS}

The authors wish to thank D. Le Bars for FAA analyses, L. Lecanu for confirmation of the identities of volatile compounds by GCmass spectrometry, and A. Gruss for reviewing the English.

\section{REFERENCES}

[1] AFNOR, Guide pour l'implantation d'un local destiné aux analyses sensorielles, NF V09-105, 1972.

[2] Bertier P., Bouroche J.M., Analyse de données multidimensionnelles, Presses Universitaires de France, Paris, France, 1981.

[3] Broome M.C., Krause D.A., Hickey M.H., The use of non-starter lactobacilli in Cheddar cheese manufacture, Aust. J. Dairy Technol. 45 (1990) 67-73.

[4] Cluzel J.P., Chopin A., Ehrlich S.D., Chopin M.C., Phage abortive infection mechanism from Lactoccocus lactis subsp. lactis, expression of which is mediated by an IsoISS1 element, Appl. Environ. Microbiol. 57 (1991) 3547-3551.

[5] Corsetti A., Gobetti M., Smacchi E., De Angelis M., Rossi J., Accelerated ripening of Pecorino Umbro cheese, J. Dairy Res. 65 (1998) 631-642.

[6] Crow V.L., Coolbear T., Goparl P.K., Martley F.G., McKay L.L., Riepe H., The role of autolysis of lactic acid bacteria in the ripening of cheese, Int. Dairy J. 5 (1995) 855-875.

[7] de Jong L., The influence of the moisture content on the consistency and protein breakdown of cheese, Neth. Milk Dairy J. 32 (1978) 1-14.

[8] Fox P.F., McSweeney P.L.H., Lynch C.M., Significance of non-starter lactic acid bacteria in Cheddar cheese, Aust. J. Dairy Technol. 53 (1998) 83-89.

[9] Gripon J.-C., Desmazeaud M.J., Le Bars D., Bergère J.L., Étude du rôle des microorganismes et des enzymes au cours de la maturation des fromages. II. - Influence de la présure commerciale, Lait 55 (1975) 502-516.

[10] Hynes E., Ogier J.-C., Delacroix-Buchet A., Proteolysis during ripening of miniature washed-curd cheeses manufactured with different strains of starter bacteria and a Lactobacillus plantarum adjunct culture, Int. Dairy J. 11 (2001) 587-597.

[11] Hynes E., Ogier J.-C., Son O., DelacroixBuchet A., Influence of starter and adjunct lactobacilli culture on ripening of miniature washed-curd cheeses, Lait 83 (2003) 17-29.

[12] IDF, Determination of nitrogen content, Standard 20B, Int. Dairy Fed., Brussels, Belgium, 1993.

[13] Kawabata S., Vassal L., Le Bars D., Cesselin B., Nardi M., Gripon J.-C., Chapot-Chartier M.P., Phage induced lysis of Lactoccocus lactis during cheese ripening and its impact on proteolysis, Lait 77 (1997) 229-239. 
[14] Kleter G., The ripening of Gouda cheese made under strictly aseptic conditions. 2. The comparison of the activity of different starters and the influence of certain Lactobacillus strains, Neth. Milk Dairy J. 31 (1977) 177-187.

[15] Lane C.N., Fox P.F., Contribution of starter and adjunct lactobacilli to proteolysis in Cheddar cheese during ripening, Int. Dairy J. 6 (1996) 715-728.

[16] Lee B.H., Laleye L.C., Simard R.E., Holley R.A., Emmons D.B., Giroux R.N., Influence of homofermentative lactobacilli on physicochemical and sensory properties of Cheddar cheese, J. Food. Sci. 55 (1990) 386-390.

[17] Lepeuple A.-S., Vassal L., Cesselin B., Delacroix-Buchet A., Gripon J.-C., ChapotChartier M.-P., Involvement of a prophage in the lysis of Lactococcus lactis subsp. cremoris AM2 during cheese ripening, Int. Dairy J. 8 (1998) 667-674.

[18] Lynch C.M., McSweeney P.L.H., Fox P.F., Cogan T.M., Drinan F.D., Contribution of starter lactococci and non-starter lactobacilli to proteolysis in Cheddar cheese with a controlled microflora, Lait 77 (1997) 441-459.

[19] Lynch C.M., Muir D.D., Banks J.M. McSweeney P.L.H., Fox P.F., Influence of adjunct cultures of Lactobacillus paracasei ssp. paracasei or Lactobacillus plantarum on Cheddar cheese ripening, J. Dairy Sci. 82 (1999) 1618-1628.

[20] Mabbit L.A., Zielinska M., Acetate agar for isolation of lactobacilli, J. Appl. Bacteriol. 19 (1956) 95-101.

[21] Martley F.G., Crow V.L., Interactions between non-starter microorganisms during cheese manufacture and ripening, Int. Dairy J. 3 (1993) 461-483.

[22] McSweeney P.L.H., Sousa M.J., Biochemical pathways for the production of flavour compounds in cheeses during ripening: a review, Lait 80 (2000) 293-324.

[23] McSweeney P.L.H., Fox P.F., Lucey J.A., Kordan K.N., Cogan T.M., Contribution of the indigenous microflora to the maturation of Cheddar cheese, Int. Dairy J. 3 (1993) 613-634.

[24] McSweeney P.L.H., Walsh E.M., Fox P.F., Cogan T.M., Drinan F.D., Castelo-Gonzalez M., A procedure for the manufacture of Cheddar cheese under controlled bacteriological conditions and the effect of adjunct lactobacilli on cheese quality, Irish J. Agric. Food Res. 33 (1994) 183-192.

[25] Naylor J., Sharpe M.E., Lactobacilli in Cheddar cheese. III. The source of lactobacilli in cheese, J. Dairy Res. 25 (1958) 431-438.
[26] Perreard E., Fromagerie d'emmental. Flore lactique «secondaire » ou d'affinage, Rev. Lait. Fr. 1 (1998) 12.

[27] Peterson S.D., Marshall R.T., Non-starter lactobacilli in Cheddar cheese: a review, J. Dairy Sci. 73 (1990) 1395-1410.

[28] Puchades R., Lemieux L., Simard R.E., Evolution of free amino acids during the ripening of Cheddar cheese containing added lactobacilli strains, J. Food Sci. 54 (1989) 885-888.

[29] Shakeel-Ur-Rehman, Banks J.M., McSweeney P.L.H., Fox P.F., Effect of ripening temperature on the growth and significance of nonstarter acid bacteria in Cheddar cheese made from raw or pasteurised milk, Int. Dairy J. 10 (2000) 45-53.

[30] Shakeel-Ur-Rehman, Banks J.M., Brechany E.Y., Muir D.D., McSweeney P.L.H., Fox. P.F., Influence of ripening temperature on the volatiles profile and flavour of Cheddar cheese made from raw or pasteurised milk, Int. Dairy J. 10 (2000) 55-65.

[31] Tailliez P., Quénée P., Chopin A., Estimation de la diversité parmi les souches de la collection CNRZ: application de la RAPD à un groupe de lactobacilles, Lait 76 (1996) 147-158.

[32] Terzaghi B.E., Sandine W.E., Improved media for lactic streptococci and their bacteriophages, Appl. Microbiol. 29 (1975) 807-813.

[33] Thomas T., Cannibalism among bacteria found in cheese, N. Z. J. Dairy Sci. Technol. 22 (1987) 215-219.

[34] Trépanier G., Simard R.E., Lee B.H., Effect of added lactobacilli on composition and texture of Cheddar cheese during accelerated maturation, J. Food Sci. 56 (1991) 696-700.

[35] Trépanier G., Simard R.E., Lee B.H., Lactic acid bacteria relation to accelerated maturation of Cheddar cheese, J. Food Sci. 56 (1991) 1238-1254.

[36] Turner K.W., Lawrence R.C., Lelievre J., A microbiological specification for milk for aseptic cheesemaking, N. Z. J. Dairy Sci. Technol. 21 (1986) 249-254.

[37] Urbach G., Relations between cheese flavour and chemical composition, Int. Dairy J. 3 (1993) 389-422.

[38] Vassal L., L'analyse sensorielle du fromage, in: Eck A. (Ed.), Le Fromage, Lavoisier, Paris, 1987, pp. 487-495.

[39] Visser S., Slangen K.J., Rollema H.S., Phenotyping of bovine milk proteins by reversed-phase high performance liquid chromatography, J. Chromatogr. 548 (1991) 361-370. 